\title{
AKULTURASI ISLAM DAN BUDAYA JAWA: Kajian Pada Ritual "Pengesahan" Warga Baru Persaudaraan Setia Hati Terate
}

\author{
Fauzan \\ IAIN Raden Intan Lampung \\ fauzan@radenintan.ac.id
}

\begin{abstract}
Abstrak
Kehadiran Islam ke wilayah Indonesia meniscayakan terjadinya dialektika antaranya dengan kebidayaan nusantara. Dialektika ini kemudian melahirkan beberapa varian keberagamaan Indonesia sebagaimana yang ditampilan dalam ritual yang ada di masyarakat. Salah satunya adalah ritual pengesahan yang dilaksanakan oleh masyarakat yang tergabung dalam Persaudaraan Setia Hati Terate. Lebih lanjut tulisan ini akan menyoroti simbolisme yang ada pada ritual pengesahan tersebut, kemudian melihatnya sebagai ekspresi keberagamaan masyarakat yang tergabung di dalamnya.
\end{abstract}

\section{Abstract}

The presence of Islam to Indonesia territory necessitates the dialectic between the kebidayaan archipelago. Dialectic is then spawned several variants of diversity of Indonesia. As is displayed in a ritual that exist in society. One of them is the Ritual Pengesahan performed by people who are members of the Persaudaraan Setia Hati Terate (PSHT). Furthermore, this paper will discus about simbolesme that there is in the ritual Pengesahan, and then see it as an expression of religious society incorporated in it.

Kata Kunci: Pengesahan, warga, PSHT, Simbol.

\section{A. Pendahuluan}

Dalam upaya melakukan kontak dengan entitas supra 
natural yang diyakini memiliki kekuatan dan pengaruh atas kehidupan di dunia, manusia menciptakan tingkah laku atau perbuatan tertentu yang disebut "ritus". Atas dasar tujuan yang ingin dicapai, pelaku yang terlibat dalam melaksanaan ritus upacara itu menyerahkan segala permasalahan dan persoalan serta pemecahannya kepada kehendak dan kebijaksanaan entitas supranatural itu. Ritus semacam itu terwujud dalam upacara keagamaan yang terdiri dari rangkaian rumus-rumus, kata, bunyi, dan gerak-gerik yang disetujui bersama oleh kelompok warga partisipan.

Dalam studi antropologi agama, ritus ${ }^{1}$ atau disebut juga upacara-upacara yang terkait dengan keyakinan keagamaan, menempati posisi penting dalam eksistensi dan pelestarian sebuah agama. Ritus keagamaan merupakan sarana yang menghubungkan manusia dengan yang keramat. Ritus bukan hanya sarana yang memperkokoh ikatan sosial kelompok dan mengurangi ketegangan, tetapi juga untuk merayakan peristiwa-peristiwa penting. ${ }^{2}$

Salah satu dari sekian banyak ritual yang berkembang dan terus dilaksanakan adalah ritual "Pengesahan" yang dilaksanakan oleh keluarga besar Persaudaraan Setia Hati Terate (PSHT). ${ }^{3}$ Ritual

${ }^{1}$ Ritus merupakan suatu sistem upacara atau prosedur magis religius, biasanya dengan bentuk-bentuk khusus kata-kata, atau suatu kosa kata tertentu (dan rahasia) dan biasanya dihubungkan dengan tindakan-tindakan atau kesempatankesempatan penting. Lihat Hartini dan G. Kartasaputra, Koamus Sosiologi dan Kependudukan, (Jakarta: Bumi Aksara, 1992), h. 358. Ritus keagamaan merupakan salah satu bagian dari sistem budaya suatu masyarakat yang memiliki fungsi, baik dalam kerangka pemenuhan kebutuhan dasar individu maupun dalam kerangka pemenuhan pertahanan hubungan masyarakat atau struktur sosial. Oleh karena itu, Merton sebagaimana dikutip Elizabeth mengatakan bahwa ritus mengandung dua fungsi utama, yaitu fungsi manifes (tampak) dan fungsi laten (terselubung). Fungsi manifest adalah konsekuensi obyektif yang memberikan sumbangan pada penyesuaian atau adaptasi sistem yang dikehendaki dan disadari langsung oleh pelaku (warga partisipan) sistem tersebut. Sementara fungsi laten adalah konsekuensi obyektif dari suatu ikhwal budaya "yang tidak dikehendaki" dan disadari langsung oleh pelakunya (warga partsipan). Lihat Elizabeth K. Nottingham, Agama dan Masyarakat, (Jakarta: Rajawali Press, 1994), h. 33.

${ }^{2}$ William A. Haviland, Antropologi, terj. Soekadijo, (Jakarta: Erlangga, 1993), h. 207.

${ }^{3}$ Persaudaraan Setia Hati Terate (PSHT) merupakan organisasi persaudaraan 
pengesahan ini dilaksanakan dalam rangka penerimaan warga atau anggota baru PSHT. Sebagaimana dinyatakan oleh Ketua Umum PSHT, Tarmadji Boedi Harsono, SE, bahwa ritual pengesahan warga baru ini terbagi dalam dua tahapan, yaitu "slametan" dan "keceran". Slametan menyajikan simbolisme tertentu yang memerlukan penjelasan lebih rinci untuk dapat dimengerti dengan benar. Penggunaan uborampe atau perlengkapan slametan seperti nasi tumpeng (buceng) misalnya, sebagai simbolisme manunggaling rasa sebagai hamba Tuhan, dan suatu upaya agar selalu mendapatkan kebaikan. Slametan yang menjadi tradisi luhur untuk mengiringi atau menandai berbagai perubahan dalam kehidupan seseorang adalah doa dan harapan sebagai ekspresi keberagamaan untuk memohon agar diberi keluasan jalan, berkah rizki, nasib baik yang itu semua disadari tidak dapat diraih tanpa interfensi Tuhan di dalamnya. Karena itu, slametan dengan berbagai istilah yang dipakai saat ini tidak lain adalah agama dalam kemasan budaya. ${ }^{5}$

Pelaksanaan ritual pengesahan warga baru PSHT ini menarik untuk dikaji karena secara keseluruhan menampilkan pola-pola keberagaman masyarakat jawa atau yang lebih dikenal dengan istilah Islam sinkretik, yaitu pola keberagamaan Islam yang terpengaruh unsur kepercayaan pra-Islam, yakni keyakinan animisme-dinamisme dan Hindu-Budha yang jauh sebelum kedatangan Islam menjadi anutan masyarakat secara mayoritas. ${ }^{6}$ Dalam pandangan Clifford Geertz, pola keberagamaan semacam ini disebut dengan Islam abangan. ${ }^{7}$ Tulisan singkat ini akan mengulas tentang simbolisme yang ada dalam ritual pengesahan tersebut, kemudian melihatnya sebagai sebuah ekspresi keberagamaan angotanya.

yang mengajarkan seni beladiri pencak silat. Berdiri pada tahun 1922 oleh Ki. Hadjar Hardjo Oetomo di Madiun.

${ }^{4}$ http;//www.lawupos.net.,Ritual Pengesahan Warga Baru PSHT, diunduh pada hari minggu, 13 Mei 2012, pukul 20:17 WIB.

${ }^{5}$ A. Kholil, Agama dan Ritual Slametan: Deskripsi-Antropologis Keberagamaan Masyarakat Jawa, dalam jurnal El-Harakah, Vol. 11, No.1 Tahun 2009, h. 48.

${ }^{6}$ Simuh, Tasawuf dan Perkembangannya dalam Islam. (Jakarta: Raja Grafindo, 1997), h. 111.

${ }^{7}$ Clifford Geertz, Religion of Java, (Glencoe: The Free Press, 1960), h. 5-6. 


\section{B. Sejarah Persaudaraan Setia Hati Terate}

Berdirinya organisasi Persaudaraan Setia Hati Terate tidak dapat dipisahkan dari kisah pendirinya, yaitu Ki Hajar Hardjo Oetomo yang lahir pada tahun 1890. Beliau adalah salah satu murid kinasih dari Ki Ngabehi Soerodowiryo - pendiri perguruan Setia Hati yang berpusat di Winongo, Madiun. Oleh karena itu, secara historis, Persaudaraan Setia Hati Terate memiliki akar kesejarahan dengan perguruan Setya Hati yang didirikan oleh Ki Ngabei Soero Diwirjo tersebut. Menurut penelitian O'ong Maryono, perkumpulan pencak silat yang didirikan oleh Ki Ngabei Soerodiwirjo ini bernama Joyo Gendilo Cipto Mulyo, dan pada tahun 1917 dirubah namanya menjadi Setya Hati. Perkumpulan Setya Hati ini menjadi perkumpulan pencak Silat pertama yang terorganisir di nusantara. ${ }^{8}$

Setelah menamatkan sekolah dasar (KLH/HIS) pada tahun 1905, Ki Hardjo Oetomo memasuki dunia kerja. Pada tahun 1905 belau bekerja di SS (PJKA) sebagai Learling Reambte di Bondowos o, Panarukan dan Tapen. Tahun 1906 bekerja sebagai Mantri Pasar wSpoor Madiun, dan diangkat menjadi Ajunt Opsioner Pasar Miliar, Dolopo, Uteran dan Pagotan. Pada tahun 1916 Ki Hardjo Oetomo bekerja di Pabrik Gula Rejo Agung, namun hanya bertahan selama satu tahun. Tahun 1917 beliau keluar dari pabrik gula dan bekerja di Rumah Gadai. Namun peerjaan inipun tidak lama dilaluinya, dan pada tahun yang sama beliau pindah bekerja di stasiun Madiun sebagai pekerja harian. Karena wataknya yang tidak senang melihat orang lain ditindas, beliau mendirikan perkumpulan "Harta Sanjaya" di tempat kerjanya untuk memberantas rentenir. Tidak berselang lama, berdiri pula VSTP atau Persatuan Pegawai Kerata Api dan beliau diangkat sebagai Hoofd Komisaris Madiun. Diriwayatkan bahwa pada tahun 1917 ini pulalah Ki Hardjo Oetomo mulai "nyantrik" atau belajar kepada Ki Ngabei Soerodiwirjo hingga disahkan menjadi anggota Setya Hati. ${ }^{9}$

${ }^{8}$ O’ong Maryono, Pencak Silat Merentang Waktu, (Yogyakarta: Putaka Pelajar, 1998), h. 73.

${ }^{9}$ Muhammad Ali, Memahami Ajaran Organisasi Persaudaraan Setia Hati Terate Dengan al-Qur'an dan Hadits, buku untuk kalangan sendiri, h. 8. Lihat juga Kumpulan Materi Ke-SH-an Persaudaraan Setia ati Terate, Diktat tidak diterbitkan. 
Berdasarkan data yang dihimpun Ki Hadjar Hardjo Oetomo adalah seorang pejuang. Pada tahun 1922 ia bergabung dan terlibat aktif dalam Serikat Islam. Bahkan ia pernah menjadi pengurus Serikat Islam di wilayah tempat tinggalnya. Guna mendukung perjuangannya, ia mendirikan perguruan silat yang diberinama SH Pemuda Sport Club. Karena keterlibatannya dalam pergerakan menentang penjajah. pada tahun 1925 Ki Hadjar Hardjo Oetomo ditangkap oleh pemerintah Belanda dan dipenjara di Cipinang, kemudian dipindahkan ke Padang selama 5 tahun. ${ }^{10}$

Setelah bebas dari penjara, Ki Hardjo Oetomo menetap di Pilang Bango Madiun. Di sini ia mengembangkan SH Pemuda Sport Club. Baru pada tahun 1942, bertepatan dengan datangnya Jepang ke Indonesia, Setia Hati Pemuda Sport Club dirubah namanya menjadi organisasi Persaudaraan Setia Hati Terate. Dan pada tahun 1950, Ki Hajar Hardjo Oetomo - sang pendiri Persaudaraan Setia Hati Terate - mendapat pengakuan dari pemerintah sebagai pahlawan perintis kemerdekaan, karena jasa-jasanya dalam perjuangan melawan penjajah Belanda. ${ }^{11}$

Saat ini organisasi Persaudaraan Setia Hati Terate bukan hanya menyebar di wilayah Indonesia, namun juga ke manca negara, yaitu ke negara-negara di berbagai benua di dunia. Struktur organisasi dibagi menjadi tingkat pusat di Madiun, tingkat cabang di setiap kabupaten di Indonesia, tingkat komisariat di perguruan tinggi dan luar negeri, tingkat ranting di setiap kecamatan, dan tingkat rayon untuk desa.

\section{Simbolisme Dalam Pengesahan Warga Baru PSHT}

Tindakan manusia dapat dibedakan ke dalam beberapa macam tingkatan, khususnya dalam penghayatannya, yaitu 1) tindakan praktis, tindakan ini sering disebut juga dengan tindakan biasa 2) tindakan pragmatis, tindakan ini setingkat lebih tinggi dari tindakan praktis; 3) tindakan efektif, dalam tindakan ini komunikasi bersifat langsung dan total, meskipun dibatasi oleh waktu; dan 4) tindakan simbolis, dalam tindakan ini komunikasi

\footnotetext{
${ }^{10}$ Ibid., h. 4 dan 8.

${ }^{11}$ Ibid., h. 10
} 
berjangka lama. ${ }^{12}$

Secara garis besar ada dua tindakan simbolis manusia, yakni tindakan simbolis dalam religi dan tindakan simbolis dalam tradisi. Salah satu unsur yang pasti ada dalam masyarakat adalah adanya sistem kepercayaan atau religi. Dalam religi manusia mengikatkan diri kepada Tuhan, menyerahkan diri, dan bergantung kepadaNya. Tuhan merupakan juru selamat sejati bagi manusia, dengan kekuatannya sendiri manusia tidak akan mampu menyelamatkan dirinya sendiri dan oleh karenanya ia menyerahkan diri. ${ }^{13}$

Menurut Koentjaraningrat, setiap religi merupakan sistem yang terdiri dari empat komponen, yaitu emosi keagamaan, sistem kepercayaan, sistem upacara religius, dan kelompok-kelompok religius. Kelompok-kelompok religius atau kesatuan-kesatuan sosial, yang menganut sistem kepercayaan tentang Tuhan dan alam gaib serta yang melakukan upacara-upacara religius biasanya berorientasi kepada sistem religi dan kepercayaan, juga berkumpul untuk melakukan upacara. ${ }^{14}$ Adapun kedudukan simbol atau tindakan simbolis dalam religi di sini adalah sebagai penghubung antara human-kosmis dan komunikasi religius lahir dan batin.

Sedangkan tindakan simbolis manusia yang kedua adalah tindakan simbolis dalam tradisi-tradisi atau adat istiadat. Dalam tindakan simbolis ini terdapat empat tingkatan, yakni tingkatan nilai budaya, sistem norma-norma, sistem hukum yang berlaku, dan tingkatan aturan khusus. Pada tingkatan nilai budaya ini berupa ide-ide yang mengkonsepsikan hal-hal yang penting dan paling bernilai dalam kehidupan masyarakat dan biasanya berakar pada emosi alam jiwa manusia, misalnya gotong royong atau sifat-sifat kerjasama berdasarkan solidaritas yang besar. Pada sistem norma-norma yang berupa nilai-nilai budaya yang sudah terkait dengan peranan masing-masing anggota masyarakat dalam lingkungannya. Misalnya peranan sebagai atasan dan bawahan dalam jenjang pekerjaan, sebagai orang tua-anak dan guru-murid.

${ }^{12}$ A. H. Baker, Manusia dan Simbol, (Jakarta: Gramedia, 1987), h. 97.

${ }^{13}$ Driyarkara, Pancasila dan Religi Mencari Kepribadian Nasional, (Yogyakarta: Jemmars, 1977), h. 27-31.

${ }^{14}$ Koentjaraningrat, Beberapa Pokok Antropologi Sosial, (Jakarta: Dian Rakyat, 1974), h. 111. 
Masing-masing peranan memiliki sejumlah norma yang menjadi pedoman tingkah-laku yang dalam bahasa Jawa disebut unggahungguh. Pada tingkatan sistem hukum yang berlaku, misalnya hukum adat perkawinan dan hukum adat kekayaan. Pada tingkatan aturan khusus, kegiatan-kegiatan yang terbatas ruang lingkupnya dalam masyarakat dan bersifat kongkrit, misalnya aturan sopansantun.

Dalam bingkai pemikiran tersebut, maka ritual pengesahan warga baru PSHT merupakan tindakan simbolis para anggotanya, baik tindakan simbolis dalam religi maupun dalam tradisi. Hal itu dapat dilihat dari penggunaan uborampe atau perlengkapan ritual pengesahan yang masing-masing mengisyaratkan doa kepada Tuhan. Hal ini merupakan tindakan religius di mana manusia mengikatkan diri kepada Tuhan, menyerahkan diri, dan bergantung kepada-Nya. Tuhan merupakan juru selamat sejati manusia, dengan kekuatannya sendiri manusia tidak akan mampu menyelamatkan dirinya sendiri dan oleh karenanya ia menyerahkan diri. ${ }^{15}$

Demikian juga halnya slametan yang digelar dalam ritual pengesahan warga baru PSHT tersebut, dimaksudkan sebagai permohonan kepada Tuhan Yang Maha Esa agar menurunkan wahyu-Nya kepada para calon warga yang akan disahkan menjadi warga, dan diharapkan juga menjadi warga Persaudaraan Setia Hati Terate yang baik, tahu benar dan salah, bisa menjadi manusai yang berbudi pekerti yang baik sehinga berguna bagi masyarakat dan negara Republik Indonesia. ${ }^{16}$

Berikutakan disajikanbeberapa uborampeatauperlengkapan yang digunakan dalam ritual pengesahan warga baru PSHT ini serta makna yang dikandungnya. Di antara perlengkapan tersebut adalah:

1. Nasi tumpeng (buceng). Tumpeng atau buceng merupakan makanan tradisional Jawa yang berbahan dasar nasi. Menurut asal sejarahnya, tumpeng bukan hanya makanan penahan lapar, namun di dalam bentuk tumpeng terdapat simbolisasi

${ }^{15}$ Driyarkara, Pancasila dan ..., h. 27-31.

${ }^{16}$ Petikan Dokumen Pribadi RTH. Hartono tentang tata cara pelaksanaan pengesahan warga baru PSHT. 
ketuhanan dalam kepercayaan masyarakat Jawa. ${ }^{17}$ Bentuk tumpeng yang kerucut merupakan simbol asal manusia dan dunia, yang mengerucut pada hubungan manusia dengan penciptanya, dan berakhir pada keputusan sang pencipta. Berasal dari perilaku manusia menuju terciptanya Manunggaling Kawula Gusti dan berujung pada sangkan paraning dumadi. Maksudnya adalah segala sesuatu yang ada di dunia ini akan berakhir pada Tuhan Yang Maha Esa. Oleh karena itu, penggunaan tumpeng dalam slametan merupakan simbol pengharapan kepada Allah SWT sang pemilik alam semesta ini supaya permohonannya terkabul. Tumpeng yang digunakan dalam acara slametan di PSHT ini berjumlah delapan jenis, yaitu:

a. Tumpeng megono, merupakan simbol permohonan kepada Tuhan agar para pendekar Setia Hati Terate memiliki sopan santun, tidak sombong meskipun memiliki kelebihan yang tidak dimiliki orang lain.

b. Tumpeng Kuat, merupakan sombol harapan agar warga PSHT memiliki ketahanan fisik dan memiliki ikatan persaudaraan yang kuat antar sesama pendekarnya.

c. Tumpeng Tulak. Merupakan simbol permohonan kepadaAllah SWT agar para pendekar PSHT dijauhkan dari balak dan musibah.

d. Tumpeng Slamet. Merupakan permohonan kepada Allah SWT agar memberi keselamatan kepada seluruh keluarga besar PSHT.

e. Tumpeng Rombyong. Merupakan simbol permohonan kepada Allah SWT agar para pendekar PSHT dapat hidup rukun, tentram, damai dan disenangi oleh warga masyarakat di manapun mereka berada.

f. Tumpeng Kabuli. Merupakan simbol permohonan kepada Allah SWT agar memberikan kesuksesan kepada pada pendekar PSHT dalam menjalani kehidupan dan memiliki derajat yang tinggi baik di sisi manusia maupun di sisi Allah SWT.

${ }^{17}$ Siti Rochani Soeparto, “Aneka Tumpeng Tradisional”, Makalah Seminar Pengenalan Budaya Jawa Melalui Tumpeng Tradisional Disertai Maknanya, di Universitas Gadjah Mada. 2008. Makalah tidak diterbitkan. 
g. Tumpeng Dinar. Merupakan simbol permohonan kepada Allah SWT agar pendekar PSHT dijauhan dari hal-hal yang buruk.

h. Tumpeng Golong. Merupakan simbol permohonan kepada Allah SWT agar menyatukan seluruh warga PSHT meskipun berasal dari golongan, suku dan agama yang berbeda. ${ }^{18}$

2. Ingkung, yaitu ayam yang dimasak secara utuh diberi bumbu tidak pedas dan santan. Ingkung bagi orang Jawa melambangkan manusia ketika masih bayi belum mempunyai kesalahan atau masih suci. Igkung juga melambangkan kepasrahan kepada Tuhan. Ayam yang dibuat ingkung disajikan dengankaki, sayap, dan leher terikat. Hal ini melambangkan bahwa manusia harus mengekang dirinya dari hawa nafsu. Kaki dan tangan jangan sembarangan berbuat yang melanggar syariat, dan mulut agar tidak mengucapkan hal-hal yang tidak perlu, apalagi jorok dan kotor. ${ }^{19}$ Jumlah ingkung yang disediakan sebanyak calon warga yang akan disahkan. Karena memang pada hakekatnya ingkung tersebut merupakan sedekah dari para calon warga. Sebelum dipotong, ayam jago tersebut dites ${ }^{20}$ terlebih dahulu oleh warga tingkat II untuk mengetahui kelayakannya sebagai syarat pengesahan. Oleh karena itu pelatih mengarahkan agar siswa mencari jago yang paling bagus dan paling disenangi sesuai ajaran Rasulullah saw untuk memberikan sedekah dengan sesuatu yang terbaik.

3. Kain mori atau kain kafan. Kain mori merupakan salah satu sarana pokok dalam acara pengaesahan warga baru. Kain mori akan diberikan kepada anggota baru sebagai tanda bahwa yang bersangkutan telah resmi menyandang gelar pendekar PSHT. Pemberian kain mori pada hakekatnya merupakan pesan moral agar setiap warga atau pendekar PSHT senantiasa mengingat bahwa suatu saat ia akan dibalut dengan kain mori atau mati.

${ }^{18}$ Muhammad Ali, Memahami Ajaran..., h. 79-80.

${ }^{19}$ Budiono Hadisutrisno, Islam Kejawen, (Yogyakarta: EULE BOOK, 2009), h. 189.

${ }^{20}$ Terkait tes jago ini, diyakini oleh warga PSHT bahwa terdapat aspek mistiknya. Ayam jago digunakan sebagai media untuk "nyondro" atau mengetahui karakteristik calon warga yang akan disahkan. Maka dalam tes jago ini, warga tingkat II PSHT akan akan menasehati calon warga yang akan disahkan. 
Hal ini mengingatkan mereka bahwa kematian merupakan ketentuan sang pencipta, bahwa setiap yang bernafas pasti akan mengalami kematian. ${ }^{21}$ Oleh karena itu, sebagai manifestasi pemahaman ini setiap warga atau pendekar PSHT tidak boleh takabur, menyombongkan diri dengan apa yang ia miliki. Meskipun memiliki keahlian bela diri, namun setiap warga PSHT tidak boleh bersikap semena-mena kepada sesama (adigang, adigung, adiguno). Sebaliknya warga PSHT harus berani dan tidak takut dalam membela kebenaran dan mewujudkan kesejahteraan alam semesta (hayuning bawono).

4. Jajan pasar, yaitu bermacam-macam makanan yang dibeli di pasar. Jumlah jajan pasar yang disediakan sebanyak neptu hari slametan, di antaranya ada Pisang Emas. Dalam tradisi Jawa, jajan pasar ini merupakan simbol harapan agar orang Jawa selalu memperoleh berkah dan kemakmuran dari Tuhan sehingga hidupnya selalu mendapatkan kelimpahan rizki.

5. Pisang raja 1 tangkep. Pisang raja merupakan simbol bahwa setiap warga PSHT harus bisa menjadi pemimpin, baik untuk dirinya sendiri maupun orang lain. Hal itu ditempuh dengan selalu berbuat agung, mulia dan berguna seperti seorang raja.

6. Daun sirih. Daun sirih yang digunakan dalam acara pegesahan adalah daun sirih yang "ketemu Ros" atau bertemu ruas daunnya. Ini menandakan ikatan persaudaraan antara sesama anggota didasari dengan hati atau niat yang suci. Persaudaraan yang sejati akan terjalin bila didasari dengan mempertemukan rasa atau hati.

7. Uang mahar. Uang mahar yang harus dibawa oleh calon warga yang akan disahkan berjumlah 36 (tiga puluh enam) sama dengan jumlah jurus yang diberikan di Persaudaraan Setia Hati Terate. Mahar ini merupakan penebus dari semua jurus yang didapatkan oleh calon warga yang akan disahkan. Sama halnya dengan mahar di dalam perkawinan adalah sebagai penebus gadis calon istrinya, kemudian dilakukan pernikahan sebagai simbol alih tanggungjawab dari orang tua kepada calon

${ }^{21} \mathrm{Hal}$ ini sesuai dengan ajaran Islam sebagaimana hadits Nabi saw. Bahwa "umatku yang paling cerdas ialah yang selalu memikirkan tentang kematian dan mempersiapkan diri dalam menghadap kematian. 
menantu. Begitu pula pengesahan yang dilakukan di PSHT adalah sebagai simbol penyerahan tanggungjawab kepada para calon pendekar untuk mengembangkan ilmu-ilmu yang pernah didapat seperti jurus, senam dan lainnya. ${ }^{22}$

8. Yoshua atau Garu, yaitu dupa yang digunakan dalam acara pengesahan PSHT sebanyak neptu hari slametan. Yoshua ini digunakan untuk mengharumkan ruangan tempat pelaksanaan pengesahan. Selain itu penggunaan yoshua ini juga dimaksudkan sebagai sombol agar para warga atau pendekar PSHT selalu menebarkan kebaikan di tengah masyarakat yang bisa mengharumkan idrinya sendiri, orang tua, organisasi PSHT dan bangsa.

9. Lilin, sebanyak calon warga yang akan disahkan. Lilin dipergunakan untukmenerangi ruang tempatacara pengesahan. Dimaksudkan agar setiap warga atau pendekar PSHT senantiasa bisa menjadi penerang kehidupan bagi lingkungannya.

10. Air, yang biasa disebut dengan air sumpah. Air adalah lambang dari watak tenggang rasa atau tepo seliro, teguh, kuat dan sentausa. Dengan demikian diharapkan agar setiap warga atau pendekar PSHT memiliki watak tenggangrasa, teguh, kuat dan sentausa dala kehidupannya.

Ritual pengesahan warga baru ini dilaksanakan pada malam hari dalam bulan Syuro atau Muharram. Penentuan malam pengesahan ini dilakukan oleh pengurus cabang dengan mempertimbangkan kesiapan warga tingkat II sebagai dewan pengesah warga baru PSHT. Biasanya pengesahan ini dilaksanakan di Balai Desa, Gedung Pertemuan, Auditorium, atau Gelanggang Olah Raga yang bisa menampung banyak orang. Adapun tahapantahapan yang dilalui dalam ritus pengesahan organisasi PSHT tersebut adalah sebagai berikut:

1. Slametan, yaitu sebuah upacara ritual komunal yang telah mentradisi dikalangan masyarakatIslamJawayang dilaksanakan untuk peristiwa penting dalam kehidupan seseorang. ${ }^{23}$

\footnotetext{
${ }^{22}$ Muhamamd Ali, Memahami Ajaran .... h. 28-29.

${ }^{23}$ Masdar Hilmi, Islam and Javanese Aculturation, Tesis, (Canada: Magister of McGill University, 1994), h. 41
} 
Peristiwa penting tersebut seperti kelahiran, kematian, pernikahan, membangun rumah, permulaan membajak sawah atau pasca panen, sunatan, perayaan hari besar, dan masih banyak lagi peristiwa-peristiwa yang dihiasi dengan tradisi slametan. ${ }^{24}$ Slametan diyakini sebagai sarana spiritual yang mampu mengatasi segala bentuk krisis yang melanda serta bisa mendatangkan berkah bagi mereka. Adapun objek yang dijadikan sarana pemujaan dalam slametan adalah ruh nenek moyang yang dianggap memiliki kekuatan magis. Di samping itu, slametan diyakini juga sebagai sarana mengagungkan, menghormati, dan memperingati ruh leluhur, yaitu para nenek moyang. ${ }^{25}$ Pada prinsipnya, menurut alam pikiran Jawa, keseluruhan bentuk slametan itu diorientasikan pada tujuan memelihara keseimbangan tatanan kosmik dalam rangka pencapaian keselamatan dan kesejahteraan hidup, karena kondisi kosmik yang transenden diyakini berhubungan erat dengan kondisi duniawai, dan hal ini membawa konsekuensi bagi kehidupan individu dan masyarakat. ${ }^{26}$ Upacara slametan pengesahan warga baru PSHT dimulai dari pukul 08.00 dan selesai rata-rata pukul 23.00. Runtut acara slametan adalah sebagai berikut:

a. Persiapan. Sebelum acara slametan dimulai, panitia menata ruangan khususnya meletakkan uborampe slametan. Nasi tumpeng (buceng) yang berjumlah 8 (delapan) jenis ditata berjajar di atas meja. Khusus ingkung, pisang raja, daun sirih dan uang mahar dimasukkan dalam besek dan dikumpulkan pada satu tempat disusun berjajar. Kemudian kain mori sejumlah siswa dibentangkan di atas besek hingga semuanya tidak kelihatan.

b. Pembukaan, biasanya dimulai pada jam 20.00 waktu setempat. Slametan dibuka oleh ketua panitia yang ditunjuk oleh cabang PSHT setempat. Biasanya ketua panitia dipilih

${ }^{24}$ Clifford Geertz, Religion of Java, (Glencoe: The Free Press, 1960), h. 11-15; 4041. Lihat juga Koentjaraningrat, Kebudayaan Jawa, (Jakarta: Balai Pustaka, 1984), h. 6

${ }^{25}$ Harkono Kamajaya, Kebudayaan Jawa: Perpaduan dengan Islam. (Yogyakarta: Ikatan Penerbit Indonesia, 1995), h. 247.

${ }^{26}$ Neils Mulder, Jawa - Thailand: Beberapa Perbandingan Sosial Budaya, (Yogyakarta: UGM Press, 1983), h. 63. 
dari anggota senior. Acara slametan ini biasanya dihadiri oleh tokoh masyarakat atau unsur muspida atau muspika setempat. Pada acara slametan ini semua warga atau pendekar PSHT wajib mengenakan seragam resmi PSHT, yaitu berwarna hitam dengan sabuk kain mori.

c. Sambutan. Setelah dilaksanakan pembukaan, acara sambutan disampaikan oleh ketua cabang dan unsur muspida atau tokoh masyarakat. Setalah acara sambutan, salah satu warga yang ditunjuk memberikan penjelasan tentang makna dari nasi tumpeng (buceng), jajan pasar, kain mori dan lain sebagainya. Inti dari penjelasan ini adalah menegaskan bahwa semua itu merupakan simbol ungkapan rasa syukur kehadirat Allah SWT atas selesainya proses pelatihan yang dilalui oleh calon warga dan akan disahkan pada malam itu. Acara kemudian ditutup dengan do'a yang dipimpin oleh warga tingkat II atau warga senior. Usai pembacaan do'a ini, kain mori yang semula dibentangkan diatasan besek berisi ingkung, pisang raja dan lainnya diangkat dan dilipat satu persatu.

d. Makan bersama. Pada acara ini sesepuh yang biasanya warga tingkat II memotong tumpeng diikuti tamu undangan dan peserta lainnya. Sampai di sini maka berakhirlah sesi slametan. Oleh karena itu seusai makan bersama, undangan yang bukan anggota atau warga PSHT dipersilahkan untuk pulang.

2. Ritual Keceran. ${ }^{27}$ Keceran merupakan acara inti dari ritual pengesahan warga PSHT. Ritual keceran biasanya dimulai dari waktu tengah malam (pukul 00.00 - selesai). Acara keceran ini

${ }^{27}$ Keceran secara bahasa berarti meneteskan benda cair. Pada ritual keceran mata para pesilat ditetesi dengan ar putih yang telah dicampur dengan ramuan tertentu dan telah dibacakan doa. Tujuannya agar penglihatan menjadi tajam, dan suci. Keceran pada aawalnya adalah acara yang digelar oleh para tokoh Tjimande Tari Kolot yang juga kiai jawara serta pejuang perintis kemerdekaan di antaranya Abah Khoer, Ayah Holiah, Ayah Horsi, Pak Endut, Pak Ocod, Pak Main dan Abah Buya sebagai sarana berkumpul setiap bulan Maulid. Tujuannya memperingati Maulid Nabi sekaligus melakukan ruatan, menyamakan persepsi menyusun strategi, menerpa kanuragan (kekuatan jiwa dan raga) sebagai bekal mengusir penjajah. http://rangrangbuana.blogspot.com //keceran Urutan Asli Seni Silat Budaya Banten. Diunduh pada hari Rabu, 23 Mei 2012. Pukul 20.35 WIB. 
hanya boleh diikuti oleh warga atau pendekar PSHT. ${ }^{28}$ Sepanjang prosesi keceran, calon warga disyaratkan dalam keadaan suci. Oleh karena itu, sebelum prosesi mulai, seluruh calon warga diminta untuk bersuci atau mengambil air wudlu. Runtut acara prosesi keceran adalah sebagai berikut:

a. Persiapan prosesi, dimana panitia mengatur tempat-tempat dan peralatan yang dijadikan sarana prosesi keceran. Sarana penting yang dipersiapkan oleh panitia adalah sebuah baki tempat air sumpah. Baki ini ditaruh di bagian depan ruangan dan biasanya diletakkan di atas meja yang agak tinggi sehingga dapat dilihat oleh seluruh calon warga. Selain itu panitia juga menyusun meja berjajar sejumlah kebutuhan. Setiap meja diberi empat buah kursi untuk ditempati oleh calon warga yang akan disahkan. Kain mori dan uang mahar (didalam lipatan kaim mori) diatur rapi di atas kursi yang akan diduduki oleh calon warga yang akan disyahkan. Panitia pengesahan dipersilahkan memeriksa jumlah uang mahar sudah sesuai atau belum. Lilin, air dalam gelas, daun sirih, klepon dan arang-arang kambang diatur rapi di atas meja calon warga.

b. Selesai pengaturan peralatan tersebut, calon warga memasuki ruangan dan berdiri dengan tertib dan tenang di sebela kursi masing-masing untuk melaksanakan do'a bersama. Selanjutnya calon warga dipersilahkan duduk di atas kursi di mana kain mori dan uang mahar diletakkan.

c. Pembacaan sumpah bersama. Memasuki ritual ini, lilin yang di atas meja masing-masing calon warga dinyalakan dan lampu besar dimatikan. Tidak ada yang boleh bersuara hingga dalam sekejap suasana menjadi hening, sunyi, dan senyap. Masing-masing calon warga diminta melihat ke arah baki yang berisi air sambil tangannya diangkat dan menunjuk ke arah baki air tersebut. Kemudian ketua dewan pengesah memimpin para calon warga untuk mengucapkan sumpah bersama-sama.

d. Selesai pengucapan sumpah, calon warga dipersilahkan

${ }^{28}$ Data tentang prosesi keceran ini diperoleh dari hasil wawancara dengan beberapa warga PSHT yang menjadi mahasiswa IAIN Raden Intan Lampung. 
duduk kebali di atas kursinya masing-masing. Ketua dewan pengesahan berdo'a dilanjutkan minum air sumpah, disusul oleh anggota dewan pengesah yang lebih senior. Kelebihan air yang sudah diminum oleh dewan pengesahan dibagikan kepada calon warga untuk diminum secara bergantian.

e. Selesai minum bersama, diteruskan makan klepon dan arang-arang kambang. Di sini warga (terutama pelatih calon warga) dipersilahkan "ndulang" atau menyuapi calon warga. Hal ini mengandung pengertian bahwa pelatih maupun warga yang lebih senior telah rela menerima calon warga menjadi warga PSHT.

f. Keceran. Proses keceran dilakukan dengan meneteskan air sumpah yang ada dalam gelas ke mata setiap calon warga. Sebelum diteteskan, dewan pengesah memilih daun sirih milik calon warga. Daun sirih yang ketemu ros (bertemu ruasnya) saja dipotong-potong oleh dewan pengesah dan dimasukkan ke dalam gelas. Selanjutnya dewan pengesah menyalami calon warga yang sudah dikecer sambil mendoakan kebaikan untuknya. Setelah dikecer, setiap calon warga diperintahkan untuk meminum air dalam gelas barang seteguk dan mengusapkan sisanya ke seluruh tubuhnya. Cara mengusapkan ini dianjurkan dimulai dari telapak tangan, muka, tangan sampai siku, rambut, telinga dan kaki sebagaimana bagian tubuh yang dibasuh saat mengambil air wudlu. Barulah kemudian mengusapkan ke bagian tubuh yang lainnya. Setelah selesai, panitia kemudian mengumpulkan uang mahar yang diduduki oleh calon warga. Adapun kain mori dikalungkan kepada masing-masing warga baru sebagai tanda bahwa mereka telah sah menjadi bagian dari keluarga besar PSHT.

\section{Ritual "Pengesahan" Sebagai Ekspresi Keberagamaan}

Secara historis, organisasi Persaudaraan Setia Hati Terate (PSHT) lahir dari rahim kebudayaan Islam-Jawa. Oleh karena itu, nilai-nilai spiritual dan tradisi yang dikembangkan di dalamnya menganut pola spiritualitas Islam-Jawa. Dalam hal ini hampir menjadi kesepakatan di kalangan studi Jawa, bahwa berdasarkan 
perilaku religiusnya, masyarakat Jawa bisa dibedakan ke dalam dua kelompok, yaitu Islam Santri dan Islam Abangan. Perilaku religius ini bisa dibedakan berdasarkan sistem kepercayaan kelompok dan partisipasinya dalam kegiatan ritual. ${ }^{29}$ Sistem kepercayaan dan praksis ritual di antara kedua kelompok religius ini menampakkan kecenderungan yang relatif berbeda.

Berdasarkan sistem kepercayaan, yang disebut dengan Islam Santri adalah sekelompok muslim saleh yang memeluk agama Islam dengan sungguh-sungguh, menjalankan perintah agama, dan berusaha membersihkan akidahnya dari perilaku syirik. Sedangkan Islam abangan adalah sekelompok muslim yang cara hidupnya masih banyak dikuasai oleh tradisi Jawa pra-Islam, unsur Islam, Budha-Hindu, dan unsur-unsur asli sebelumnya. ritual yang diajarkan Islam secara baku seperti shalat, puasa, ibadah haji, mengaji. Sementara Islam abangan lebih berorientasi pada ritualritual yang tidak diajarkan secara baku seperti slametan, ngruwat, tirakat, sesajen, dan sebagainya. Sebagaimana dinyatakan Simuh, bahwa masyarakat Jawa, sebagai komunitas yang dalam ukuran tertentu telah terislamkan memang memeluk agama Islam, namun dalam prakteknya, pola-pola keberagamaan mereka tidak jauh dari pengaruh unsur keyakinan dan kepercayaan pra-Islam, yakni keyakinan animisme-dinamisme dan Hindu-Budha yang jauh sebelum kedatangan Islam menjadi anutan masyarakat secara mayoritas. ${ }^{30}$

Koentjaraningrat menyebut religiusitas Islam Abangan dengan istilah Agami Jawi dan Islam Santri dengan Agama Islam Santri. Kategori ini nampaknya untuk membedakan dua varian religius dan bukan varian sosial seperti santri, priyayi, dan abangan. Yang dimaksudkan Koentjaraningrat dengan Agami Jawi adalah suatu kompleks keyakinan dan konsep-konsep HinduBudha yang cenderung ke arah mistik, yang tercampur menjadi satu dan diaku sebagai agama Islam. Sementara itu, Agama Islam Santri lebih dekat pada dogma-dogma Islam baku. ${ }^{31}$ Dengan kata

${ }^{29}$ Zaini Muchtarom, Santri dan Abangan di Jawa, (Jakarta, INIS, 1988), Jilid II, h. $1,6,7$

${ }^{30}$ Simuh, Tasawuf dan ..., h. 111.

${ }^{31}$ Koentjaraningrat, Kebudayaan Jawa..., h. 312. 
lain, Islam Abangan atau Agami Jawi lebih bersifat sinkretis karena menyatukan unsur-unsur pra-Hindu, Hindu-Budha dan Islam (heterodoks). Sementara Islam Santri lebih bersifat puritan karena mereka mengikuti ajaran agama secara ketat (ortodoks).

Dalam konteks anggota Persaudaraan Setia Hati Terate, meskipun fenomena dari dua varian keagamaan tersebut ada, namun praktisi dari keduanya tidak konsisten dengan identitas masing-masing. Dalam pemahaman A. Khalil, anggota PSHT tersebut berada pada wilayah kelabu, yaitu daerah di mana banyak individu dalam komunitas tersebut tidak jelas posisinya, santri, abangan, atau di antara keduanya. Di dalam organisasi ini, santri hidup berdampingan dengan abangan. Atau dalam organisasi ini terjadi kompromi, tidak konsisten, dan ambivalen yang tidak dapat ditangkap oposisi kategorial santri versus abangan. Memang kita perlu menelusuri hubungan orang satu sama lain yang membedakan orientasi sehari-hari dalam komunitas yang bercampur baur tanpa batasan yang jelas dan kaku. Di kalangan komunitas yang heterogen sekarang ini, tidak ada perbedaan besar antara santri dan yang lain berkaitan dengan praktik keberagamaan, terutama mengenai slametan atau yang disebut kenduri maupun syukuran. ${ }^{32}$

Fakta pada ritual pengesahan warga baru PSHT menunjukkan bahwa terdapat kelompok santri yang memiliki pengetahuan agama Islam dengan baik, atau bahkan berasal dari pesantren, mereka menerima ritual pengesahan tersebut, meskipun di dalamnya terdapat praktek-praktek yang tidak diajarkan oleh Islam. Dalam hal ini mereka mencoba memahami apa yang ada dalam ritual tersebut sebagai simbol dalam berhubungan dengan Allah SWT. Mereka berupaya memahami dan menjelaskan ritual pengesahan itu dengan dalil agama Islam, sebagaimana yang dilakukan oleh Muhammad Ali, salah seorang warga PSHT alumni Pondok Pesantren Walisongo Ngabar Ponorogo. Dalam bukunya yang berjudul Memahami Ajaran Organisasi Persaudaraan Setia Hati Terate Dengan al-Qur'an dan Hadits, Muhammad Ali berupaya menjelaskan lambang, tradisi, dan falsafah hidup (berupa semboyan dan kata mutiara) yang ada di PSHT dengan dalil-dalil

${ }^{32}$ A. Kolil, Agama dan Ritual Slametan..., h. 89-90. 
al-Qur'an dan Hadits. ${ }^{33}$

Pemahaman kelompok santri yang demikian tentu saja akan berbeda dengan anggota organisasi ini yang berada pada wilayah abangan. Pemahaman serta pola keberagamaan kelompok kedua ini lebih diwarnai aroma mistisisme jawa. Sebagaimana ditunjukkan oleh pemahaman mereka terhadap air sumpah dan kain mori. Air sumpah bagi kelompok kedua ini memiliki nilai mistis yang bisa membawa keberkahan, keselematan dan lain-lain, sehingga mereka berusaha mendapatkan air sumpah pada ritual pengesahan tersebut. Demikian juga pemahaman mereka terhadap kain mori yang sangat mereka sakralkan. Mereka percaya bahwa dalam kain mori tersebut memiliki kekuatan magis tertentu yang bisa digunakan oleh pemiliknya.

Meskipun memiliki pemahaman yang berbeda, kedua kelompok ini mampu hidup berdampingan dengan rukun tanpa ada yang mempermasalahkan keberadaan pemahaman masingmasing. Dalam hal ini hubungan mereka direkatkan dengan doktrin persaudaraan antar sesama warga. Doktrin ini terasa begitu dominan dalam hubungan keanggotaan organisasi ini, bahkan mampu menegasikan sekat psikologis akibat perbedaan etnis, agama, dan lainnya.

\section{E. Penutup}

Bahwa apa yang terjadi pada ritual pengesahan warga baru PSHT merupakan satu bentuk ekspresi keagamaan masyarakat (Jawa). Hal ini semakin mengukuhkan bahwa melihat corak keberagamaan Islam di Indonesia -khususnya Jawa- dari satu sudut pandang saja hanya akan menjadikan pandangan terdistorsi dan tidak utuh. Ada kompleksitas dan pernik-pernik yang butuh pengamatan yang lebih mendalam, yang tidak bisa dilihat hanya sepintas lalu. Di sana kadang terdapat pergulatan cukup serius antara Islam dan kepercayaan-kepercayaan pra-Islam, negosiasi Islam dan budaya lokal, serta proses saling mempengaruhi satu sama lain yang kadang berwujud dalam pola sinkretis, konflik, atau pola-pola lain yang kadang sulit untuk didefinisikan. Dalam konteks ritual pengesahan ini, simbolisme yang terdapat di

${ }^{33}$ Muhammad Ali, Memahami Ajaran ... 
dalamnya, serta proses ritual itu sendiri menunjukkan ekspresi keberagamaan anggotanya yang menambah ragam keberagamaan Islam di Indonesia. [ ]

\section{Daftar Pustaka}

A. Kholil, Agama dan Ritual Slametan: Deskripsi-Antropologis Keberagamaan Masyarakat Jawa, dalam jurnal El-Harakah, Vol. 11, No.1 Tahun 2009.

Muhammad Ali, Memahami Ajaran Organisasi Persaudaraan Setia Hati Terate Dengan al-Qur'an dan Hadits, buku untuk kalangan sendiri,

A. H. Baker, Manusia dan Simbol, Jakarta: Gramedia, 1987.

Dokumen Pribadi RTH. Hartono tentang tata cara pelaksanaan pengesahan warga baru PSHT.

Driyarkara, Pancasila dan Religi Mencari Kepribadian Nasional, Yogyakarta: Jemmars, 1977.

Clifford Geertz, Religion of Java, Glencoe: The Free Press, 1960.

Budiono Hadisutrisno, Islam Kejawen, Yogyakarta: EULE BOOK, 2009.

Hartini dan G. Kartasaputra, Koamus Sosiologi dan Kependudukan, Jakarta: Bumi Aksara, 1992.

William A. Haviland, Antropologi, terj. Soekadijo, Jakarta: Erlangga, 1993.

Masdar Hilmi, Islam and Javanese Aculturation [Tesis], Canada: Magister of McGill University, 1994.

http://rangrangbuana.blogspot.com //keceran Urutan Asli Seni Silat Budaya Banten. Diunduh pada hari Rabu, 23 Mei 2012. Pukul 20.35 WIB.

http;//www.lawupos.net.,Ritual Pengesahan Warga Baru PSHT, diunduh pada hari minggu, 13 Mei 2012, pukul 20:17 WIB.

Harkono Kamajaya, Kebudayaan Jawa: Perpaduan dengan Islam, Yogyakarta: Ikatan Penerbit Indonesia, 1995.

Koentjaraningrat, Beberapa Pokok Antropologi Sosial, Jakarta: Dian Rakyat, 1974. , Kebudayaan Jawa, Jakarta: Balai Pustaka, 1984. 
Kumpulan Materi Ke-SH-an Persaudaraan Setia ati Terate, Diktat tidak diterbitkan.

O’ong Maryono, Pencak Silat Merentang Waktu, Yogyakarta: Putaka Pelajar, 1998.

Zaini Muchtarom, Santri dan Abangan di Jawa, Jakarta, INIS, 1988, Jilid II.

Neils Mulder, Jawa - Thailand: Beberapa Perbandingan Sosial Budaya, Yogyakarta: UGM Press, 1983.

Elizabeth K. Nottingham, Agama dan Masyarakat, Jakarta: Rajawali Press, 1994.

Simuh, Tasawuf dan Perkembangannya dalam Islam, Jakarta: Raja Grafindo, 1997.

Siti Rochani Soeparto,, “Aneka Tumpeng Tradisional”, Makalah Seminar Pengenalan Budaya Jawa Melalui Tumpeng Tradisional Disertai Maknanya, di Universitas Gadjah Mada. 2008. Makalah tidak diterbitkan. 